Research.

\title{
THE INFLUENCE OF PROFITABILITY RATIOS, CAPITAL STRUCTURE AND SHAREHOLDING STRUCTURE AGAINST ON VALUE COMPANY (EMPIRICAL STUDY OF COAL MINING COMPANIES LISTED ON THE STOCK EXCHANGE OF INDONESIA YEAR 2011-2013)
}

\author{
By: \\ Gilang Ramadhan Fajri and Dwi Asih Surjandari
}

\begin{abstract}
This study has the objective to assess the "Influence of Profitability Ratios, Capital Structure and Shareholding Structure Against On Value Company (Empirical Study of Coal Mining Companies Listed on the Stock Exchange of Indonesia Year 2011-2013)" The analysis technique used in this research is multiple linear regression and hypothesis testing using $t$ statistic to test the partial regression coefficient and $f$-statistic to test the feasibility of the research model with a $10 \%$ level of significance. It also conducted a classic assumption test including normality test, multicolinearity test, heteroscedasticity test and autocorrelation test. Based on the results of the study indicate that Profitability Return on equity positive effect on firm value. Earning pershare significant positive effect on the value of the company. The capital structure has a positive effect on firm value. institutional ownership has significant negative effect on the value of the company. Managerial ownership negatively affect the value of the company.
\end{abstract}

Keywords: Profitability Ratios, Institutional Ownership, Managerial Ownership, Capital Structure, Corporate Values.

\section{INTRODUCTION}

At the moment, the purpose of company is not only to derive profit optimal, but increase value of enterprise by prosperity their owner to other purposes from the company (apriyada, 2013). The owner of Company said when shareholders have benefit from every shares on an investment who invested. The advantage gained among others can come of net profits of companies and can come from the increase in the price of stocks of companies at the Indonesian stock exchange. By the company shares means the increase in the value the company own

The phenomenon in this research that examines the importance of value the company because of "increasing the company's value that indicates the prosperity of shareholders also increased". But besides the usual profitability also lowered the value of the company, this can happen because in improving profitability, the company will increase its operations so that the costs resulting from this activity will also increase.

Reasons of profitability, capital structure and ownership structure is a factor that affects the value of the company, which in turn affect the company's performance in achieving the company's goal is the maximization of corporate value. This is due to control that is owned by the shareholders. With the supervision of external parties, running of the company can be controlled so as to achieve its goals. The structure of ownership shares in companies generally includes institutional ownership, managerial ownership, and ownership by an individual or the public. The study of factors decline in coal issuer's financial performance is very important to determine the effect on profitability, capital structure, ownership and value of the issuer's shares of coal companies, so it can be a reference to measure the financial performance of issuers of coal. To answer these problems researchers using agency theory and signaling theory, while the research

Gilang Ramadhan Fajri and Dwi Asih Surjandari: Influence of Profitability Ratios, Capital Structure and Shareholding Structure Against on Value Company (Empirical Study of Coal Mining Companies Listed on The Stock Exchange of Indonesia Year 2011-2013) 
method used in this study is intended to examine and explain the patterns of relationships between two or more variables that this type of support theories have been required as a cornerstone in forward the hypothesis and to find criteria measurement of the relationship between variables variables studied, including research through the testing of hypotheses, sampling technique used in this study through purposive sampling. This study replicates research (Apriyada, 2013) and researchers focused on a mining company to gain information on the financial statements. The reason for choosing mining companies in this study because it is based on some of the phenomena that occur at this time, namely a decrease in coal prices caused a decline in profits in the financial performance and stockprice.

Based on the background of the problems that have been described can be formulated:

1. Is Profitability Ratios affect the Company Values?,

2. Is the capital structure affect the value of the firm? And

3. Is the effecton Share holding Structure of Company Value?

Based on the formulation of the problem and the research background, the purpose of this research is:

1. For Assessing the impact of Profitability Ratios of the Company Values.

2. For Assessing the impact of the Capital Structure of the Company's value.

3. For Assessing the impact of the ownership structure to invesments the value of company. This study is expected to give a specific picture to the company about the importance of profitability, ownership structure, capital structure to improve aspects of the value of the company so that the company is getting better in the eyes of the community and provide an overview to investors about the importance of considering the aspects related to the value of the company with how to analyze more depth when the investor will undertake investment activities with a view aspects of profitability, capital structure and ownership.

\section{LIBRARY REVIEW, RESEARCH PARADIGM, AND HYPOTHESES OF THE RESEARCH}

Theory signals indicate asymmetry of information between the management company and the parties with an interest in such information. According to Wolk et al (2000) signal theory explaining the reason of company is presenting the information to the capital markets. Signal theory put forward about how the company should provide signals to users of financial statements. Signal theory rooted in the pragmatic accounting theory focuses on the influence of information on changes in user behavior information. One of the information that can be used as the signal is the announcement made by an issuer. This announcement will be able to affect the price fluctuations of securities companies issuers that do announcements (Suwardjono, 2005).

1. Theory Agency (Agency Theory) Jensen and Meckling (1976) states that an agency relationship is a contract between the manager (agent) to the investor (principal). The manager is a party contracted by the shareholders to work in the interests of shareholders. For that management is given the power to make decisions in the best interest of shareholders. Therefore, the management shall be accountable for all his efforts to the shareholders. Agency relationship is said to have occurred when a contract between a person or more, a principal, an agent and others to provide services in the interests of the principal, including involving the awarding delegates decision-making power to the agent (Belkaoi, 2007). Neither the principal nor the agent is assumed to be motivated only by self-interest, which is to maximize the usefulness of the subject and also to be aware of their common interests. Agencies strive to maximize contract payments that depend on a certain level of effort required.

2. Corporate Values Value is created when the company returns to its investors exceed the cost of capital. Value for investor company can be reached only by contributing value to customers (Sudana, 2008). The main purpose companies according to theory of the firm is to maximize the wealth of the company or the enterprise value (value of the firm) (Salvatore, 2005). Maximizing the value of the company is very important for a company, because to maximize value also means maximizing shareholder wealth is the ultimate goal of the company (Soliha and Taswan, 2002). The value of the company is willing to pay the price a prospective buyer if the company is sold.

Gilang Ramadhan Fajri and Dwi Asih Surjandari: Influence of Profitability Ratios, Capital Structure and Shareholding Structure Against on Value Company (Empirical Study of Coal Mining Companies Listed on The Stock Exchange of Indonesia Year 2011-2013) 
3. Profitability, Profitability is a picture of a managing company profitability measure can share a kind as operating income, net income, the level of development of investment or asset and return on equity owner. Home and Wachowicz (2010) say that the profitability ratio consists of two is the ratio that indicates profitability in relation to sales (gross profit margin and the margin Labat clean) and provitablitity in connection with less investment is return on assets $(R O A)$ and return on equity (ROE ). Profitability is the end result of a number of policies and decisions of the management company (Brigham and Houston (2011).

4. Capital structure, Capital structure theory to explain the influence changes in capital structure to the company's value, the current investment decisions and dividend policy is held constant, in other words if the companies revamp most of its own capital by using debt or conversely whether the stock price will also change, however, if the changing structure the capital value of the company turned out to also change, it will get a conclusion about the best capital structure. In the decision, careful consideration needs to be done in order to determine the source of the funds which will be used in the operational activities of the company. The right decision will be able to increase the value of the company.

5. Shareholding Structure

a. Institutional Ownership, Institutional ownership is the proportion of share ownership by institutional investors. Institutional investors are believed to have the ability of monitor management actions better than individual investors. Institutions as shareholders considered more capable in detecting errors that occur. Lee et al. (1992) If the change in current profits are not perceived benefit by the investor, the investor can liquidate their shares. Institutional investors typically have large amounts of stock, so if they liquidate its stock will affect the overall value of the stock. To avoid liquidation actions of investors, managers will conduct earnings management.

b. Ownership managerial, Managerial stock ownership is the largest stock holdings by company management. Siallagan and Machfoedz (2006) conducted a study on the effect of managerial ownership on the quality of earnings with discretionary accrual and the company's value, as measured by Tobin 's $Q$, concluded the test results that managerial ownership affect positively on the quality of earnings, whereas the effect of managerial ownership on firm value is negative. Ownership management is the proportion of shareholders from management who actively participate in corporate decision-making by directors and commissioners (Diyah and Widanar, 2009).

\section{RESEARCH METHOD}

In carrying out this study, researchers used a type of causal research with a view to hypotheses test about the effects of four independent variables on the dependent variable dependen. Variabel or dependent is the variable that is affected or which become due for their independent variables. Bound or dependent variable in this study is the value of the company. The company's value is proxied by Price to Book Value (PBV).

Free or independent variable is the variable that affects or is the cause of the change or the emergence of the dependent variable or bound. Free or independent variable in this study is the shareholding structure consisting of institutional ownership, managerial ownership, capital structure and profitabilitas. Pengukuran variable is a variable definition given in order to give meaning or specify them.

Population is the generalization region consisting of objects or subjects that have certain qualities and characteristics defined by the researchers to learn and then drawn conclusions (Sugiyono, 2010).

Data collection method used in this research is the method of observation, namely data collection techniques by observation of aspects that can be a historical record or records are now public or private company. In this study, data collection was done by means observe, record and analyze the financial statements of the company-owned coal mining company listed on the website of PT. Indonesia Stock Exchange is www.idx.co.id.

Gilang Ramadhan Fajri and Dwi Asih Surjandari: Influence of Profitability Ratios, Capital Structure and Shareholding Structure Against on Value Company (Empirical Study of Coal Mining Companies Listed on The Stock Exchange of Indonesia Year 2011-2013) 


\section{RESULT AND DISCUSSION}

This study uses mining company listed on the Indonesia Stock Exchange as samples. Based on the criteria of samples and sampling procedures have been done acquired 18 companies with 54 years of observations in the sample.

Table 1. Descriptive statistics

\begin{tabular}{|l|l|l|l|l|l|} 
Descriptive Statistics & \multicolumn{5}{l|}{} \\
\hline & $N$ & Minimum & Maximum & Mean & Std. Deviation \\
\hline ROE & 54 & -203.00 & 214.00 & 9.2431 & 52.77618 \\
EPS & 54 & -34.9000 & 79.2000 & 4.681480 & 21.4583805 \\
DER & 54 & -1251.50 & 947.10 & 38.3820 & 226.08857 \\
Kep. Institusional & 54 & 7.50 & 54.62 & 31.1781 & 8.98415 \\
Kep. Manajerial & 54 & 36.00 & 92.50 & 66.9028 & 10.68394 \\
PBV & 54 & -.0048 & 72.3500 & 7.524574 & 16.1215693 \\
\hline
\end{tabular}

The average value of institutional ownership $(\mathrm{KI})$ of 54 samples amounting to 31.17 percent greater than the value of the standard deviation data at 8.98, which means every 100 shares of the total shares of the company average coal mining enterprises produce 31.17 shares institutional ownership.

The average value of managerial ownership (KM) during the observation period 2011-2013 amounted to 66.9 per cent with a standard deviation of 10.68 , which means every 100 shares of the total shares of the company average coal mining enterprises produce 66.9 shares ownership managerial.

The average value of enterprise value (PBV) during the observation period (2011-2013) by 7.52 percent with a standard deviation of 16.12 , which means every 100 Book value per share, the average of coal mining enterprises produce a 7:52 market price per share.

\section{Clasic Assumtions Test}

\section{Normality Test.}

Table 2. One-Sample Kolmogorov-Smirnov Test

One-Sample Kolmogorov-Smirnov Test

\begin{tabular}{|c|c|c|}
\hline & & Standardized Residual \\
\hline \multirow{2}{*}{$\begin{array}{l}\text { N } \\
\text { Normal } \\
\text { Parameters }{ }^{a, b} \\
\text { Most Extreme } \\
\text { Differences } \\
\text { Test Statistic }\end{array}$} & $\begin{array}{l}\text { Mean } \\
\text { Std. Deviation }\end{array}$ & $\begin{array}{l}54 \\
.0000000 \\
.95166190\end{array}$ \\
\hline & $\begin{array}{l}\text { Absolute } \\
\text { Positive } \\
\text { Negative }\end{array}$ & $\begin{array}{l}.223 \\
.223 \\
-.165 \\
.223\end{array}$ \\
\hline \multicolumn{2}{|c|}{ Asymp. Sig. (2-tailed) } & $.386^{c}$ \\
\hline
\end{tabular}

Kolmogrov-Smirnov value of 0.223 with a significance value of 0.386 . Which means that the table above sig $=0.386>0.1$, so $\mathrm{H} 0$ is not rejected, which means that residual data is normally distributed.

Gilang Ramadhan Fajri and Dwi Asih Surjandari: Influence of Profitability Ratios, Capital Structure and Shareholding Structure Against on Value Company (Empirical Study of Coal Mining Companies Listed on The Stock Exchange of Indonesia Year 2011-2013) 


\section{Multikolinearity Test}

Table 3. Variance inflation faktor (VIF)

\begin{tabular}{|l|l|l|}
\hline \multirow{2}{*}{ Model } & \multicolumn{2}{|l|}{ Collinearity Statistics } \\
\cline { 2 - 3 } & Tolerance & VIF \\
\hline (Constant) & & \\
ROE & .938 & 1.066 \\
\hline EPS & .956 & 1.046 \\
DER & .946 & 1.058 \\
Kep. Institusional & .346 & 2.893 \\
Kep. Manajerial & .342 & 2.921 \\
\hline
\end{tabular}

Values above 0.1 tolerances all variables and the variance inflation factor (VIF) all the variables under 10 . Thus five of variables can be used to predict the value of the company PBV during the observation period.

\section{Heteroskedastisity Test}

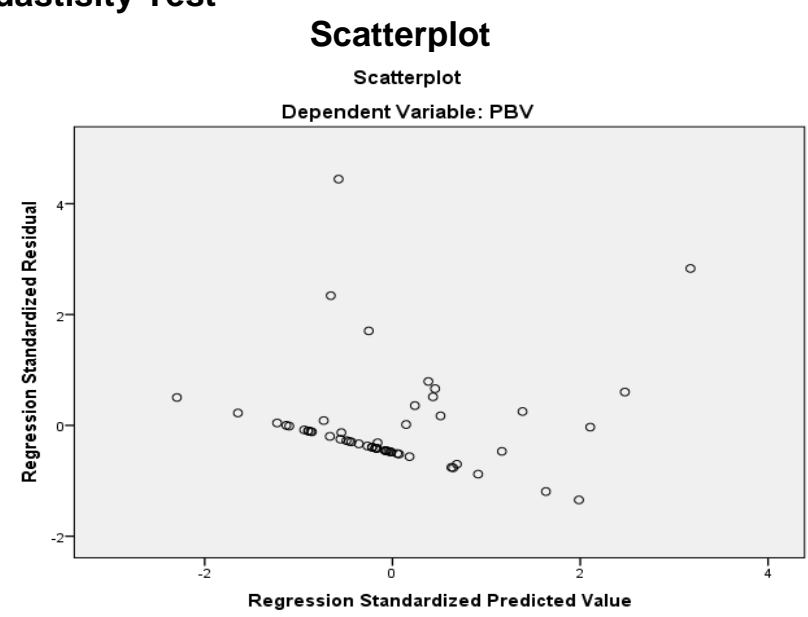

From the scatterplot graph seen that the dots randomly spread and spread both above and below the zero (0) on the $Y$ axis, do not gather in one place, and does not form a specific pattern so that it can be concluded that there is no heteroscedasticity.

Table 4. Glejser Test

\begin{tabular}{|c|c|c|c|c|c|c|}
\hline \multirow[b]{2}{*}{ Mode } & & \multicolumn{2}{|c|}{$\begin{array}{l}\text { Unstandardized } \\
\text { Coefficients }\end{array}$} & \multirow{2}{*}{$\begin{array}{l}\text { Standardized } \\
\text { Coefficients } \\
\text { Beta }\end{array}$} & \multirow[b]{2}{*}{$\mathrm{T}$} & \multirow[b]{2}{*}{ Sig. } \\
\hline & & $\mathrm{B}$ & Std. Error & & & \\
\hline \multirow[t]{5}{*}{1} & $\begin{array}{l}\text { (Constant) } \\
\text { ROE }\end{array}$ & $\begin{array}{l}63.906 \\
.045\end{array}$ & $\begin{array}{l}33.659 \\
.041 \\
\end{array}$ & .147 & $\begin{array}{l}1.899 \\
1.082 \\
\end{array}$ & $\begin{array}{l}.064 \\
.285 \\
\end{array}$ \\
\hline & $\overline{E P S}$ & .192 & .101 & .255 & 1.898 & .064 \\
\hline & DER & .009 & .010 & .125 & .928 & .358 \\
\hline & Kep. Institusional & -.827 & .401 & -.461 & -2.061 & .055 \\
\hline & Kep. Manajerial & -.482 & .339 & -.320 & -1.423 & .161 \\
\hline
\end{tabular}

a. Dependent Variable: PBV

Gilang Ramadhan Fajri and Dwi Asih Surjandari: Influence of Profitability Ratios, Capital Structure and Shareholding Structure Against on Value Company (Empirical Study of Coal Mining Companies Listed on The Stock Exchange of Indonesia Year 2011-2013) 
From the output above it can be seen that the significant value of the five independent variables more than 0.1 . It can be concluded that no problem heteroscedasticity in regression models.

\section{Autocorrelation Test}

Table 5. Durbin Watson Test

\begin{tabular}{|l|l|l|l|l|l|}
\hline Model & $\mathrm{R}$ & R Square & $\begin{array}{l}\text { Adjusted R } \\
\text { Square }\end{array}$ & $\begin{array}{l}\text { Std. Error of } \\
\text { the Estimate }\end{array}$ & Durbin-Watson \\
\hline 1 & $.413^{\mathrm{a}}$ & .171 & .084 & 15.4254356 & 2.125 \\
\hline
\end{tabular}

Based on the result of the Durbin-Watson 2.125; whereas in table Durbin-Watson (DW) for the "k" = 4 and $\mathrm{N}=54$ large Durbin-Watson - table: $\mathrm{dl}$ (outer boundary) $=1.6950$ and $\mathrm{du}$ (limit in) $=1.7948 ; 4-\mathrm{du}=2.2052$ and $4-\mathrm{dl}=2.305$. Therefore the value of Durbin-Watson (DW) 2.125 greater than the limit (du) 1.7948 and the Durbin-Watson (DW) less than 2.2052, it can be concluded that the Durbin-Watson (DW) -test can not reject $\mathrm{HO}$ stating that there is no positive or negative autocorrelation or it can be concluded there is no autocorrelation.

\section{Multiple Reggressions Analysis}

\section{Determination Coefficient $\left(\mathbf{R}^{2}\right)$}

Table 6. Determination Coefficient $\left(\mathbf{R}^{2}\right)$

Model Summary ${ }^{b}$

\begin{tabular}{|l|l|l|l|l|}
\hline Model & $R$ & R Square & $\begin{array}{l}\text { Adjusted R } \\
\text { Square }\end{array}$ & $\begin{array}{l}\text { Std. Error of the } \\
\text { Estimate }\end{array}$ \\
\hline 1 & $.413^{\mathrm{a}}$ & .171 & .084 & 15.4254356 \\
\hline
\end{tabular}

Means the influence of the independent variable on the dependent variable is the enterprise value (PBV) of only 0,084 or equal to $8.4 \%$. The remaining value of 0.916 or equal to $91.6 \%$ is explained by other variables not included in this study.

\section{F Test (Test of influence simultaneously)}

\section{Table 7 Simultaneous F Test}

\section{ANOVA ${ }^{\mathrm{a}}$}

\begin{tabular}{|ll|l|l|l|l|l|}
\hline \multicolumn{2}{|l|}{ Model } & Sum of Squares & Df & Mean Square & F & Sig. \\
\hline 1 & Regression & 2353.650 & 5 & 470.730 & 1.978 & $.099^{\mathrm{b}}$ \\
& Residual & 11421.315 & 48 & 237.944 & & \\
& Total & 13774.965 & 53 & & & \\
\hline
\end{tabular}

$\mathrm{H}_{0}$ : independent variables together no significant effect on the dependent variable $\mathrm{H}_{1}$ : independent variables jointly significant effect on the dependent variable

\section{Resulation}

In the table above sig $=0.099<0.1$, so $\mathrm{H}_{0}$ is rejected, therefore, it can be concluded that simultaneous, profitability, return on equity (ROE), Earning Pershare (EPS), capital structure (DER), institutional ownership (KI) , managerial ownership (KM) significantly influence the company's variable value (PBV).

Gilang Ramadhan Fajri and Dwi Asih Surjandari: Influence of Profitability Ratios, Capital Structure and Shareholding Structure Against on Value Company (Empirical Study of Coal Mining Companies Listed on The Stock Exchange of Indonesia Year 2011-2013) 


\section{3. $\quad t$ test (Test the effect of partially)}

Tabel 8. $t$ test (Test the effect of partially)

\begin{tabular}{|l|r|r|r|r|r|}
\hline \multirow{2}{*}{ Model } & \multicolumn{2}{|c|}{$\begin{array}{c}\text { Unstandardized } \\
\text { Coefficients }\end{array}$} & \multicolumn{2}{c|}{$\begin{array}{c}\text { Standardized } \\
\text { Coefficients }\end{array}$} & \multicolumn{1}{c|}{$\mathrm{t}$} \\
\cline { 2 - 6 } & \multicolumn{1}{c|}{$\mathrm{B}$} & \multicolumn{1}{c|}{ Std. Error } & \multicolumn{2}{c|}{ Beta } \\
\hline (Constant) & 63.906 & 33.659 & & 1.899 & .064 \\
\hline ROE & .045 & .041 & .147 & 1.082 & .285 \\
\hline EPS & .192 & .101 & .255 & 1.898 & .064 \\
\hline DER & .009 & .010 & .125 & .928 & .358 \\
\hline Kep. Institusional & -.827 & .401 & -.461 & -2.061 & .055 \\
\hline Kep. Manajerial & -.482 & .339 & -.320 & -1.423 & .161 \\
\hline
\end{tabular}

PBV $=63096+0.045 *$ ROE +0.192 * EPS $+0.009 *$ DER -0.827 * Kep. Institusional $0.482 *$ Kep. Manajerial

\section{DISCUSSION}

1. Return on equity (ROE) positive effect on firm value. The results of this study are consistent with the results of research and Taswan Soliha (2002) and Sujono and Soebiantoro (2007) who found evidence of return on equity has positive effect on firm value. High profit prospects will give an indication of a good company that can trigger investors to increase demand for stocks.

2. Earning Pershare (EPS) significant positive effect on firm value research results concur with those of Carlson and Bathala (1997) and Chen and Steiner (1999) who found evidence of earnings Pershare positive effect on firm value. Earning Pershare assess the revenue generated each share of common stock.

3. Capital structure (DER) a positive effect on the value of the company. The results of this study are not consistent with the results of research Safrida (2008) which showed that the capital structure negatively affect the value of the company. This study shows that when firms use more debt than equity as a funding source so the effect on the declining value of the company.

4. Institutional shareholding significant negative effect on the value of company results of this study are not consistent with the results of research and Mamduh Ismiyanti (2003) and Slovin and Sushka (1993) which shows that the institutional share ownership a positive effect on the value of the company. This means showing that the higher the institutional ownership, the stronger the external control of the company.

4. Managerial stock ownership negative effect on the value of the company. The results of this study are consistent with the results of research and Machfoedz Siallangan (2006) which showed that managerial ownership negative effect on the value of the company. The low managerial ownership in a company that is less proactive managerial work in realizing the interests of shareholders and will eventually undermine confidence, then the value of the company declined.

Gilang Ramadhan Fajri and Dwi Asih Surjandari: Influence of Profitability Ratios, Capital Structure and Shareholding Structure Against on Value Company (Empirical Study of Coal Mining Companies Listed on The Stock Exchange of Indonesia Year 2011-2013) 


\section{CONCLUSION AND SUGGESTIONS}

\section{Conclusion}

1. Profitability positive effect on the value of the company higher profit will give an indication of the company's prospects are good that could trigger investors to increase demand for stocks.

2. This study shows that the capital structure has a positive impact on corporate value, or in other words when the capital structure shows the increase in the value of the company will experience a rise in vice versa.

3. This means shows that the higher the institutional ownership, the stronger the external control of the company. The existence of institutional ownership will encourage more optimal monitoring of corporate performance in achieving corporate goals is to optimize the value of the company.

4. The effect of the independent variable on the dependent variable is the enterprise value (PBV) of only 0,084 or equal to $8.4 \%$. The remaining value of 0.916 or equal to $91.6 \%$ is explained by other variables not included in this study.

\section{Implication}

1. Effect of Profitability Ratios at Corporate Value Profitability in this study was measured by using Return on equity (ROE) and Earning Pershare (EPS) as one of the profitability ratio is a very important indicator for investors. The higher the level of profitability achieved by the company, the higher the value of the company, so as to increase the value of the company, the company must improve.

2. Its performance Effect of Capital Structure on Firm Value Capital structure in this study was measured by debt-to-equity ratio (DER) is the ratio of total debt held company with total equity of the company. Debt to equity ratio measures the ability of the company's own capital as collateral all debts by Brigham et al. (2011) companies with a low debt to equity will have a small risk of loss when the state of the economy in decline, but when the economic conditions improve, the opportunity to earn profits too low.

3. Effect on Shareholding Structure of Company Value The shareholding structure in this study was measured by the percentage of shares held by institutional investors and management.

\section{Suggestions}

1. The study was only done on a coal mining company listed on the Indonesia Stock Exchange, subsequent research can do research with different objects eg, company financial and banking sector, the manufacturing sector, the property sector and the agricultural sector to obtain the consistency of the results.

2. This study uses only the value of the company to assess the performance of the company and earnings per share. It is intended to develop this research to assess the financial ratio, liquidity ratio, solvency ratio and others that can be used to assess the performance of companies like ROA, ROI, dividend policy, cash ratio, current ratio, TIE (time interest earned) and others ,

\section{REFERENCES}

Apriyada, K. (2013). Pengaruh Struktur Kepemilikan Saham, Struktur Modal dan Profitabilitas Terhadap Nilai Perusahaan. Denpasar: Jurnal IImiah Universitas Udayana.

Belkaoui, Ahmed R. 2007. Accounting Theory.Buku 2. Jakarta: Salemba Empat.

Bon, Kim Jeong, Krinsky, Itzhak, dan Lee, Jason.1993. Motives for Going Public and Underpricing: New Findings from Korea. Journal of Business Financial and Accounting. January. p. 195-211.

Brigham, E. F. \& Houston, (2011). Dasar-dasar Manajemen Keuangan, Edisi Sebelas, Alih Bahasa Ali Akbar Yulianto, Penerbit Salemba Empat, Jilid 2, Jakarta.

Gilang Ramadhan Fajri and Dwi Asih Surjandari: Influence of Profitability Ratios, Capital Structure and Shareholding Structure Against on Value Company (Empirical Study of Coal Mining Companies Listed on The Stock Exchange of Indonesia Year 2011-2013)

Page : 64 
Carlson, S.J. dan Bathala,C.T. 1997. Ownership Differences and Firm"s Income, Smoothings Behaviour. Journal of Business Finance \& Accounting, 24 (2),179-196.

Chen, R. Carl, dan Steiner, T.L. 1999. Managerial Ownership and Agency Conflict: A Nonlinear Simultaneous Equation Analysis of Managerial Ownership, Risk Taking, Debt Policy and Dividend Policy, Financial Review, Vol. 34, pp. 119-137.

Christiawan, Yulius, J., \& Tarigan, J. (2007). Kepemilikan Manajerial: Kebijakan Hutang, Kinerja dan Nilai Perusahaan, Jurnal Akuntansi dan Keuangan Vol 9. No.1, 22-23.

Diyah, Pujiati, dan Widanar, Erman. 2009. "Pengaruh Struktur Kepemilikan terhadap Nilai Perusahaan: Keputusan Keuangan sebagai Variabel Intervening. "Jurnal Ekonomi Bisnis dan Akuntansi Ventura, Vol. 12. No. 1, h. 71-86.

Fama, E. F. 1978. "The Effect of a Firm"s Investmentand Financing Decisionon the Welf are of its Security Holders. "American Economic Review 68: June 272-284.

Gallagher, Timothy J. And Joseph D. 2007. Financial Management. Prentice Hall, inc, united state of America.

Ghozali, Imam. 2011. Aplikasi Analisis Multivariate dengan Program SPSS. Semarang: Badan Penerbit Universitas Diponegoro.

Graham, John, Scott Smart, and William Megginson (2010), Corporate Finance (3rd Edition), Cengage South-Western

Horne, James C. V., dan Wachowicz, John M. 2005. Fundamental of Financial Management. Buku Satu Edisi Keduabelas. Jakarta: Salemba Empat.

Ismiyanti , F \& Mamduh, M. H. (2004). Struktur Kepemilikan, Risiko, dan Kebijakan Keuangan: Analisis Persamaan Simultan. Jurnal Ekonomi dan Bisnis Indonesia, Vol 19, No 2, 176196.

Jama"an. 2008. Pengaruh Mekanisme Corporate Governance, dan Kualitas Kantor Akuntan Publik terhadap Integritas Informasi Laporan Keuangan (Studi Kasus Perusahaan publik yang Listing di BEJ). Semarang: Universitas Diponegoro.

Jensen, M.C. dan Meckling, W. H. 1976. Theory of The Firm : Managerial Behavior, Agency Costs and Ownership Structure. Journal of Financial Economics, Oktober, 1976, V. 3, No. 4, pp. 305-360. Avalaible from: audit Delay, Vol.10, No.3, h.109-121.

Keown, Arthur, J, et al, (2011). Dasar-Dasar Manajemen Keuangan. Diterjemahkan oleh Chaerul D Djakman. Edisi Ketujuh. Buku 1. Jakarta: Salemba Empat.

Kusumajaya, D. K. O. 2011. Pengaruh Struktur Modal dan Pertumbuhan Perusahaan terhadap Profitabilitas dan Nilai Perusahaan pada Perusahaan Manufaktur di Bursa Efek Indonesia. Universitas Udayana, Denpasar: Tesis yang Tidak Dipublikasikan.

Lee, C. Rosentein, SN, Rangan, dan Davidson III , W.N. 1992 ."Board Compositionand Shareholder Wealth: The Case of Management Buyout". Financial Management, 21:58-72.

Modigliani, F dan Miller,M. 1963. Corporate Income Taxses and The Cost of Capital: A Correction, American Economic Review, 53, June, pg. 433-443.

Morck, R., Shleifer, A.,\& Vishny, R.W. (1988). Management Ownership and Market Valuation: An Empirical Analysis. Journal of Financial Economics, Vol. 20, hal. 293-315.

Gilang Ramadhan Fajri and Dwi Asih Surjandari: Influence of Profitability Ratios, Capital Structure and Shareholding Structure Against on Value Company (Empirical Study of Coal Mining Companies Listed on The Stock Exchange of Indonesia Year 2011-2013) 
Mulyadi. 2007. Activity Based Cost System. Ed. 6. Yogyakarta: UPP STIM YKPN.

Permanasari, W.I. (2010). Pengaruh Kepemilikan Manajemen, Kepemilikan Institusional dan Corporate Social Responsibility terhadap Nilai Perusahaan Jurnal Ekonomi dan Bisnis. Universitas Diponegoro 22, 21-28.

Rachmawati, Andri dan Hanung Triatmoko, 2007. Analisis Faktor-Faktor yang Memengaruhi Kualitas Laba dan Nilai Perusahaan. Disampaikan pada Simposium Nasional Akuntansi (SNA)X Makassar.

Riswari, Dyah Ardana. 2012. "Pengaruh Corporate Social Responsibility terhadap Nilai Perusahaan dengan Corporate Governance sebagai Variabel Moderating. Tesis tidak dipublikasikan. Universitas Diponegoro.

Rodoni, Ahmad dan Herni Ali, (2010). Manajemen Keuangan. Edisi Pertama. Jakarta: Mitra Wacana Media.

Ross, S. 1977. The Determination of Financial Structure : the Icentive Signalling Approach, Bell Jounal of Economics, 8, 23-40.

Safrida, Eli. 2008. Pengaruh Struktur Modal dan Pertumbuhan Perusahaan terhadap Nilai Perusahaan pada Perusahaan Manufaktur di Bursa Efek Jakarta. Tesis Publikasi. Universitas Sumatra Utara. Medan.

Salvatore, Dominick. 2005. Ekonomi Manajerial dalam Perekonomian Global. Salemba Empat: Jakarta.

Satmoko, A \& Sudarman. (2011). Impact of Personal Taxes on Corporate Dividend Policy and Capital Structure Decisions, Finance Management. Financial Management Association. 19 (2), pp. 21-31.

Sawir, Agnes, 2009. Analisa Kinerja Keuangan dan Perencanaan Keuangan Perusahaan, PT. Gramedia Pustaka Utama, Jakarta.

Shiller, R. J. dan Pound, J. 1989. Survey Evidence on The Di_usion of Interest and Information among Investors. Journal of Economic Behavior and Organization12 (1), 47-66.

Siallagan, Hamonangan dan Machfoedz, M. 2006. Mekanisme Corporate Governance, Kualitas Laba dan Nilai Perusahaan. Disampaikan pada Simposium Nasional Akuntansi (SNA) IX Padang.

Sitepu, Citra Noveli. 2010. Pengaruh Kinerja Keuangan terhadap Harga saham pada Perusahaan Industri Makanan dan Minuman yang Terdaftar di BEI, Jurnal Akuntansi, Universtias Sumatera Utara Fakultas Ekonomi Medan.

Slovin, Myron B. dan Sushka, Merie E. 1993. Ownership Concentration, Corporate Control Activity, and Firm Value: Evidence from The Death of Inside Block Holder, Journal of Finance; Vol. XLVII, No. 4. 30-50.

Smith, Michael P. 1996. "Shareholder Activision by Institusional Investor, Evidence fro, Calpers", Journal of Finance, Vol. XLI, No. 1. 45-70.

Sofyaningsih, Sri dan Hardiningsih, Pancawati. 2010. Struktur Kepemilikan, Kebijakan Dividen, Kebijakan Utang dan Nilai Perusahaan. Universitas Stikubank.

Gilang Ramadhan Fajri and Dwi Asih Surjandari: Influence of Profitability Ratios, Capital Structure and Shareholding Structure Against on Value Company (Empirical Study of Coal Mining Companies Listed on The Stock Exchange of Indonesia Year 2011-2013)

Page : 66 
Soliha, Evis dan Taswan. 2002. Pengaruh Kebijakan Hutang terhadap Nilai Perusahaan Serta Faktor yang Memengaruhinya. Dalam Jurnal Bisnis dan Ekonomi, STIE Stikubank Semarang. (online), (www.google.com).

Sri, S. \& Pancawati, H. (2010). Struktur Kepemilikan, Kebijakan Dividen, Kebijakan Utang dan Nilai Perusahaan. Universitas Stikubank.

Subramanyam, K. R. 1996. "The Pricing of Discretionary Accruals". Journal of Accounting and Economics, pp. 249-281. Retrieved: March2 ${ }^{\text {nd }}$, 2007, from ProQuest Database.

Sujono dan Soebiantoro, Ugy. 2007. Pengaruh Struktur Kepemilikan Saham, Leverage, Faktor Intern dan Faktor Ekstern terhadap Nilai Perusahaan (Studi Empiric pada Perusahaan Manufaktur dan Non Manufaktur di Bursa Efek Jakarta). Dalam Jurnal Manajemen dan Kewirausahaan,9(1): h:43-47.

Suwardjono. 2005. Teori Akuntansi: Perekayasaan Pelaporan Keuangan (Edisi III). Yogyakarta: BPFE.

Syafri Harahap, Sofyan, 2008. Analisa Kritis atas Laporan Keuangan, PT. Raja Grafindo Persada, Jakarta.

Wahyudi, Untung dan Pawestri, H.P. 2006. Implikasi Struktur Kepemilikan terhadap Nilai Perusahaan: Dengan Keputusan Keuangan Sebagai Variabel Intervening. Disampaikan pada Simposium Nasional Akuntansi (SNA) IX Padang.

Wening, Kartikawati. 2009. "Pengaruh Kepemilikan Institusional terhadap Kinerja Keuangan.

Wolk, Harry, Michael G. Tearney, dan James L Dodd. 2000. Accounting Theory: A Conceptual and Institutional Approach. South - Western College Publishing.

Financeroll.co.id

http://societykamaru.blogspot.com

http://www.realminers.com

www.idx.co.id

www.sahamok.com

Gilang Ramadhan Fajri and Dwi Asih Surjandari: Influence of Profitability Ratios, Capital

Structure and Shareholding Structure Against on Value Company (Empirical Study of

Coal Mining Companies Listed on The Stock Exchange of Indonesia Year 2011-2013) 
The Accounting Journal of BINANIAGA Vol. 01, No. 02, 2016

This page intentionally be emptied.

Gilang Ramadhan Fajri and Dwi Asih Surjandari: Influence of Profitability Ratios, Capital Structure and Shareholding Structure Against on Value Company (Empirical Study of Coal Mining Companies Listed on The Stock Exchange of Indonesia Year 2011-2013)

Page : 68 